\title{
Association between the CTLA-4 +49A/G polymorphism and Graves' disease: A meta-analysis
}

\author{
XIAOYU SI ${ }^{1,2}$, XIUFENG ZHANG ${ }^{1}$, WENRU TANG $^{1,2}$ and YING LUO $^{1,2}$ \\ ${ }^{1}$ Faculty of Environmental Science and Engineering and ${ }^{2}$ Laboratory of Molecular Genetics of Aging and Tumor, \\ Faculty of Life Science and Technology, Kunming University of Science and Technology, \\ Kunming, Yunnan 650500, P.R. China
}

Received March 31, 2012; Accepted June 14, 2012

DOI: $10.3892 /$ etm.2012.618

\begin{abstract}
The $+49 \mathrm{~A} / \mathrm{G}$ polymorphism of the cytotoxic T-lymphocyte-associated antigen-4 gene (CTLA-4) has been associated with Graves' disease (GD). However, results have been inconsistent. The aim of this study was to quantitatively summarize the evidence for CTLA- $4+49 \mathrm{~A} / \mathrm{G}$ polymorphism and GD. Electronic search of PubMed was conducted to select studies. Case-control studies containing available genotype frequencies of CTLA- $4+49$ were chosen, and odds ratio (OR) with $95 \%$ confidence interval (CI) was used to assess the strength of this association. Forty-two case-control studies including 8,288 cases and 9,372 controls were identified. Three studies were eliminated from the total 42 studies due to a p-value $<0.05$ (p-value for Hardy-Weinberg equilibrium in control group) in these studies which induced significant publication bias. The overall results suggested that the variant genotypes were highly associated $(\mathrm{p}<0.01)$ with GD risk in all genetic models (additive model: OR, 1.443; 95\% CI, 1.319-1.578; $\mathrm{p}<0.001$; recessive model: OR, 1.589; 95\% CI, 1.396-1.808; p<0.001; dominant model: OR, 1.621; 95\% CI, 1.430-1.837; p<0.001). Similarly, in the subgroup analyses for ethnicity (Caucasian, Asian), the results were positive. This meta-analysis suggests that the CTLA-4 +49A/G polymorphism is highly associated $(\mathrm{p}<0.01)$ with increased risk of GD, especially in Caucasians and Asians. To validate this association, further studies with larger participants worldwide are needed to examine associations between this polymorphism and GD.
\end{abstract}

\section{Introduction}

Graves' disease (GD) is one of the autoimmune thyroid diseases (AITDs) which affect $5 \%$ of the general population (1). GD is an

Correspondence to: Dr Ying Luo or Dr Wenru Tang, Faculty of Environmental Science and Engineering, Kunming University of Science and Technology, 727 Jing Ming Nan Road, Chenggong, Kunming, Yunnan 650500, P.R. China

E-mail: yingluo@kmust.edu.cn

E-mail:twr@sina.com

Key words: cytotoxic T-lymphocyte-associated antigen-4 gene, autoimmune thyroid diseases, Graves' disease, meta-analysis autoimmune antibody-mediated, thyroid-specific autoimmune disease which causes thyroid gland tumefaction. GD patients make antibodies to the thyroid-stimulating hormone receptor leading to hyperthyroidism. People of Western countries $(\sim 1.2 \%)$ and $0.25-1.09 \%$ of people of China are afflicted with GD (2,3). Although environmental factors, such as infection (4) and stress, are very important in the process of Graves' disease in susceptible individuals, one study in twins revealed that $\sim 80 \%$ of the predisposition to GD is due to genetic factors (5). Several genetic loci have been implicated in the susceptibility to this disease. One of the associated genes is the cytotoxic T-lymphocyte-associated antigen-4 (CTLA-4) gene which consists of 4 exons and 3 introns. In 1997, Yanagawa et al (6), Marron et al (7) and Donner et al (8) initially reported that there was an association between CTLA4 and Graves' disease. The CTLA-4 gene is located on the long arm of chromosome $2 q 33$ and belongs to the immunoglobulin superfamily. Since the CTLA-4 protein transmits an inhibitory signal to T-cells, it has a strong susceptibility in autoimmunity. One of the CTLA-4 gene polymorphisms is located on exon $1+49$, which causes a threonine to alanine substitution in codon 17 (codon $17 \mathrm{~T} / \mathrm{A}$ ). To date, the CTLA-4 +49A/G polymorphism has been studied in different and numerous groups in humans, and a potential association with GD has been found in many results (6-36). However, some results suggest that there is no association between CTLA-4 +49A/G polymorphism and GD (37-46). Thus, the results are still inconsistent. Another problem is that these published studies only refer to a rather modest sample size that limits their significance. Utilizing the advantage of metaanalysis, a powerful method for quantitatively summarizing different study results, we combined the data for analysis and increased the sample size to a reasonable level. In this study, we conducted a meta-analysis to quantitatively assess the effect of the CTLA- $4+49 \mathrm{~A} / \mathrm{G}$ polymorphism on the risk of GD.

\section{Materials and methods}

Publication search. PubMed was searched using the terms 'CTLA 4', 'Graves' and 'polymorphism' or 'CTLA4', 'Graves' and 'polymorphism' or 'cytotoxic T lymphocyte', 'Graves' and 'polymorphism' (the last search update was on March 11, 2012). Case-control studies containing available genotype frequencies of 49A/G were chosen. Additional studies were 


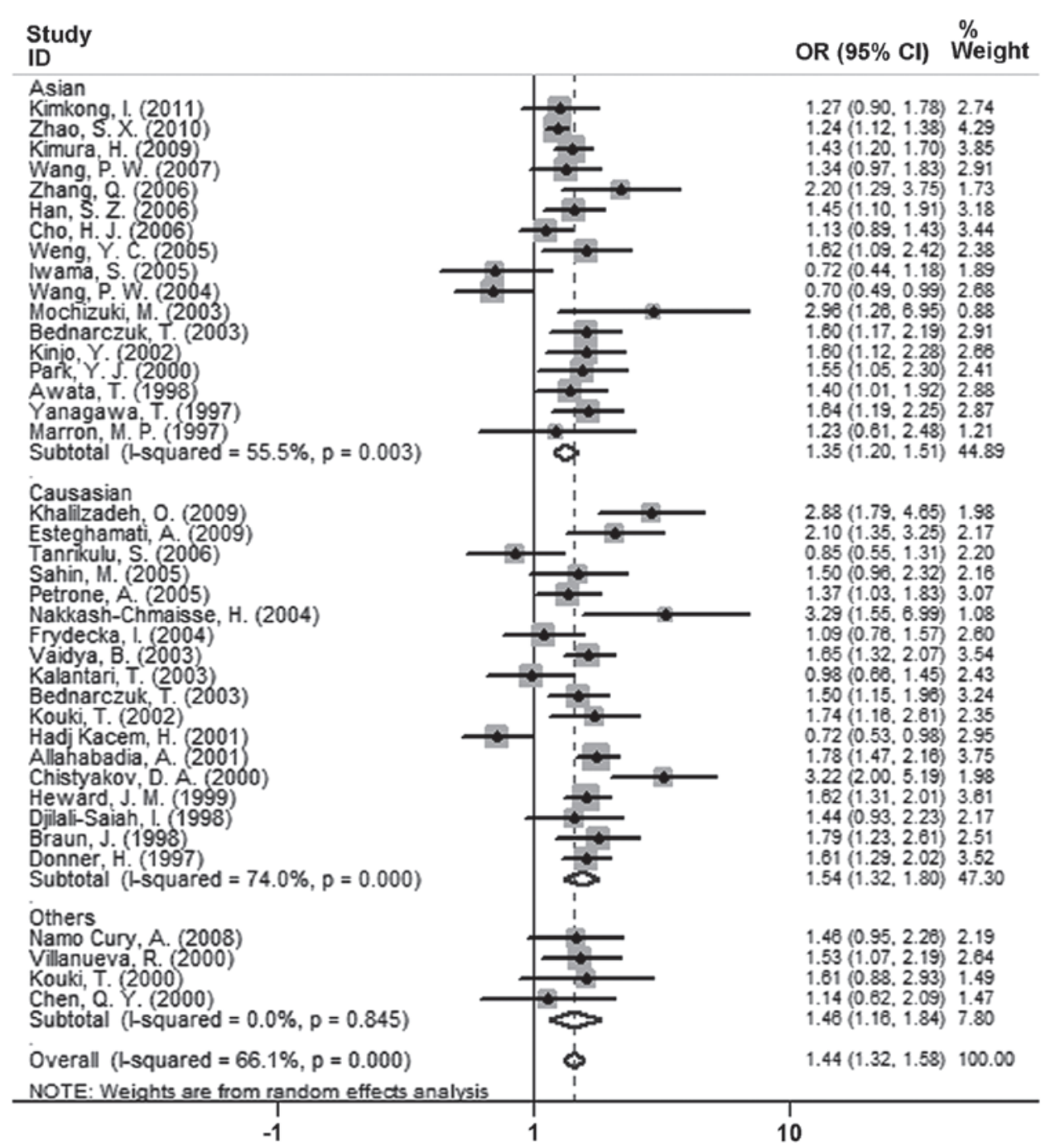

Figure 1. Forest plot of ORs of the G allele when compared to the A allele (additive model) in the Graves' patients. The squares and horizontal lines correspond to the study-specific OR and $95 \%$ CI. The area of the squares reflects the study-specific weight. The diamond represents the pooled OR and $95 \%$ CI. OR, odds ratio; $\mathrm{CI}$, confidence interval.

identified by a manual search of the references of the original studies.

Statistic analysis. For the control group of each study, the observed genotype frequencies of the CTLA-4 +49A/G polymorphism were assessed for Hardy-Weinberg equilibrium using the $\chi^{2}$ test. The strength of association between the $+49 \mathrm{~A} / \mathrm{G}$ polymorphism of the CTLA-4 gene and GD was assessed by calculating crude odds ratios (ORs) with 95\% confidence intervals (CIs). The pooled ORs were performed for the additive genetic model ( $\mathrm{G}$ vs. A), dominant model $(\mathrm{G} / \mathrm{G}+\mathrm{G} / \mathrm{A}$ vs. $\mathrm{A} / \mathrm{A})$ and recessive model $(\mathrm{G} / \mathrm{G}$ vs. $\mathrm{G} / \mathrm{A}+\mathrm{A} / \mathrm{A})$, respectively. Heterogeneity assumption was checked by a $\chi^{2}$-based Q-test. A p-value of $<0.05$ for the Q-test indicated a lack of heterogeneity among the studies; the summary OR estimate of each study was calculated by the random effects model $(47,48)$. The potential for publication bias was examined by Begg's test (funnel plot method) and Egger's linear regression test $(\mathrm{p}<0.05$ was considered representative of statistical significance) (49). All statistical analyses were performed with Stata software (version 11.0; Stata Corporation, College Station, TX).

\section{Results}

Eligible studies. We identified 42 case-control studies concerning the association between the CTLA-4 +49A/G polymorphism and GD, which included 8,288 GD cases and 9,372 controls. These data were used in our meta-analysis (Table I). The distribution of genotypes in the controls of all the studies was in agreement with Hardy-Weinberg equilibrium.

Meta-analysis. The results of the association between the CTLA-4 +49A/G polymorphism and GD and the heterogeneity test are shown in Table II. The overall results suggest that the variant genotypes were highly associated $(\mathrm{p}<0.01)$ with GD risk in all genetic models [additive model: OR, 1.443; 95\% CI, 1.319-1.578; p<0.001 (Fig. 1); recessive model: OR, 1.589; 95\% CI, 1.396-1.808; p<0.001 (Fig. 2); dominant model: OR, 1.621; 95\% CI, 1.430-1.837; p<0.001 (Fig. 3)]. Similarly, 
Table I. Distribution of the CTLA-4 +49A/G genotype for patients with Graves' disease and the controls.

\begin{tabular}{|c|c|c|c|c|c|c|c|c|c|c|}
\hline \multirow[t]{2}{*}{ Population } & \multirow{2}{*}{$\begin{array}{l}\text { Ethnicity or } \\
\text { origin }\end{array}$} & \multirow[t]{2}{*}{ Study } & \multirow[b]{2}{*}{ Year } & \multicolumn{3}{|c|}{ GD } & \multicolumn{3}{|c|}{ Control } & \multirow[b]{2}{*}{ P-value } \\
\hline & & & & $\mathrm{A} / \mathrm{A}$ & $\mathrm{A} / \mathrm{G}$ & $\mathrm{G} / \mathrm{G}$ & $\mathrm{A} / \mathrm{A}$ & $\mathrm{A} / \mathrm{G}$ & $\mathrm{G} / \mathrm{G}$ & \\
\hline Caucasian & South Indian & Veeramuthumari et al (9) & 2011 & 11 & 37 & 32 & 29 & 25 & 26 & 0.000819 \\
\hline Asian & Thai & Kimkong et al (37) & 2011 & 22 & 49 & 61 & 26 & 73 & 54 & 0.875319 \\
\hline Asian & Chinese Han & Zhao et al (10) & 2010 & 104 & 730 & 1030 & 156 & 823 & 945 & 0.211832 \\
\hline Asian & Japanese & Kimura et al (11) & 2009 & 62 & 143 & 210 & 142 & 358 & 295 & 0.067982 \\
\hline Caucasian & Iranian & Khalilzadeh et al (12) & 2009 & 48 & 43 & 14 & 75 & 25 & 3 & 0.606930 \\
\hline Caucasian & Iranian & Esteghamati et al (13) & 2009 & 114 & 71 & 20 & 75 & 25 & 3 & 0.606930 \\
\hline Others & Brazilian & Namo Cury et al (38) & 2008 & 43 & 58 & 15 & 39 & 32 & 7 & 0.905523 \\
\hline Asian & Chinese & Chong et al (14) & 2008 & 7 & 73 & 97 & 24 & 56 & 71 & 0.028090 \\
\hline Asian & Taiwanese & Wang et al (15) & 2007 & 15 & 69 & 124 & 18 & 77 & 97 & 0.633099 \\
\hline Asian & Chinese & Zhang et al (16) & 2006 & 2 & 29 & 58 & 7 & 26 & 27 & 0.846451 \\
\hline Caucasian & Turkish & Tanrikulu et al (17) & 2006 & 48 & 38 & 11 & 42 & 34 & 14 & 0.120930 \\
\hline Asian & Chinese & Han et al (18) & 2006 & 33 & 95 & 135 & 32 & 89 & 75 & 0.520341 \\
\hline Asian & Korean & Cho et al (39) & 2006 & 16 & 112 & 160 & 30 & 197 & 244 & 0.240107 \\
\hline Asian & Taiwanese & Weng et al (40) & 2005 & 8 & 53 & 46 & 15 & 58 & 28 & 0.091603 \\
\hline Caucasian & Turkish & Sahin et al (19) & 2005 & 29 & 33 & 15 & 43 & 48 & 7 & 0.189953 \\
\hline Caucasian & Italian & Petrone et al (20) & 2005 & 59 & 68 & 23 & 139 & 138 & 24 & 0.201228 \\
\hline Asian & Japanese & Iwama et al (41) & 2005 & 17 & 25 & 1 & 78 & 88 & 34 & 0.287293 \\
\hline Asian & Taiwanese & Wang et al (21) & 2004 & 18 & 72 & 81 & 11 & 50 & 87 & 0.316477 \\
\hline Caucasian & Lebanese & Nakkash-Chmaisse et al (22) & 2004 & 8 & 23 & 3 & 24 & 14 & 0 & 0.163933 \\
\hline Caucasian & Polish & Frydecka et al (42) & 2004 & 32 & 50 & 17 & 50 & 84 & 20 & 0.096480 \\
\hline Caucasian & White & Vaidya et al (23) & 2003 & 88 & 139 & 74 & 146 & 158 & 45 & 0.825642 \\
\hline Asian & Japanese & Mochizuki et al (24) & 2003 & 1 & 6 & 13 & 12 & 27 & 21 & 0.539129 \\
\hline Caucasian & Iranian & Kalantari et al (25) & 2003 & 21 & 49 & 20 & 30 & 53 & 30 & 0.510214 \\
\hline Caucasian & Polish & Bednarczuk et al (26) & 2003 & 75 & 123 & 66 & 77 & 85 & 32 & 0.303455 \\
\hline Asian & Japanese & Bednarczuk et al (26) & 2003 & 28 & 140 & 151 & 15 & 63 & 34 & 0.093804 \\
\hline Asian & Chinese & Yung et al (27) & 2002 & 3 & 54 & 66 & 23 & 59 & 76 & 0.046372 \\
\hline Caucasian & USA & Kouki et al (28) & 2002 & 22 & 67 & 31 & 30 & 36 & 14 & 0.576150 \\
\hline Asian & Japanese & Kinjo et al (32) & 2002 & 32 & 62 & 50 & 38 & 46 & 26 & 0.107271 \\
\hline Caucasian & Tunisian & Hadj Kacem et al (30) & 2001 & 31 & 63 & 50 & 26 & 94 & 85 & 0.998814 \\
\hline Caucasian & $\begin{array}{l}\text { UK } \\
\text { Caucasian }\end{array}$ & Allahabadia et al (43) & 2001 & 136 & 262 & 86 & 192 & 198 & 34 & 0.081624 \\
\hline Others & $\begin{array}{l}\text { African, } \\
\text { American, } \\
\text { Hispanic, } \\
\text { Asian }\end{array}$ & Villanueva et al (44) & 2000 & 42 & 67 & 28 & 53 & 52 & 16 & 0.568526 \\
\hline Asian & Korean & Park et al (31) & 2000 & 5 & 35 & 57 & 26 & 75 & 98 & 0.061219 \\
\hline Others & Not specified & Kouki et al (32) & 2000 & 8 & 29 & 8 & 15 & 23 & 5 & 0.390573 \\
\hline Caucasian & Moscow & Chistyakov et al (33) & 2000 & 6 & 22 & 50 & 25 & 38 & 30 & 0.081864 \\
\hline Others & $\begin{array}{l}\text { African- } \\
\text { American }\end{array}$ & Chen et al (45) & 2000 & 20 & 25 & 4 & 23 & 19 & 5 & 0.718804 \\
\hline Caucasian & UK & Heward et al (34) & 1999 & 122 & 192 & 65 & 164 & 171 & 28 & 0.067423 \\
\hline Caucasian & White & Djilali-Saiah et al (46) & 1998 & 23 & 37 & 13 & 47 & 37 & 16 & 0.069793 \\
\hline Caucasian & $\begin{array}{l}\text { German, } \\
\text { Canadian }\end{array}$ & Braun et al (35) & 1998 & 22 & 56 & 25 & 52 & 48 & 21 & 0.096985 \\
\hline Asian & Japanese & Awata et al (36) & 1998 & 11 & 44 & 57 & 58 & 197 & 170 & 0.938310 \\
\hline Asian & Japanese & Yanagawa et al (6) & 1997 & 11 & 64 & 78 & 34 & 88 & 78 & 0.287293 \\
\hline Asian & Chinese & Marron et al (7) & 1997 & 1 & 11 & 16 & 6 & 39 & 49 & 0.632129 \\
\hline Caucasian & $\begin{array}{l}\text { German, } \\
\text { Canadian }\end{array}$ & Donner et al (8) & 1997 & 81 & 161 & 63 & 135 & 149 & 41 & 0.990935 \\
\hline
\end{tabular}

${ }^{a} \mathrm{p}$-value for Hardy-Weinberg equilibrium in the control group. GD, Graves' disease. 
Table II. ORs and 95\% CI for the CTLA-4 +49A/G polymorphism for different genetic models in patients with Graves' disease.

\begin{tabular}{|c|c|c|c|c|c|c|c|}
\hline Genetic model & Population & Pooled OR & R (95\% CI) & P-value & $\begin{array}{l}\text { Heterogeneity } \\
\text { P-value }\end{array}$ & $\begin{array}{l}\text { Begg's test } \\
\text { P-value }\end{array}$ & $\begin{array}{c}\text { Egger's test } \\
\text { P-value }\end{array}$ \\
\hline \multirow{4}{*}{$\begin{array}{l}\text { Additive } \\
\text { (G vs. A) }\end{array}$} & Asian & 1.347 & $(1.203-1.507)$ & $<0.001$ & 0.003 & 0.323 & 0.373 \\
\hline & Caucasian & 1.543 & (1.324-1.798) & $<0.001$ & $<0.001$ & 0.426 & 0.788 \\
\hline & Others & 1.458 & $(1.157-1.837)$ & 0.001 & 0.845 & 0.174 & 0.505 \\
\hline & Overall & 1.443 & $(1.319-1.578)$ & $<0.001$ & $<0.001$ & 0.255 & 0.642 \\
\hline \multirow{4}{*}{$\begin{array}{l}\text { Recessive } \\
\text { (G/G vs. A carriers) }\end{array}$} & Asian & 1.476 & $(1.267-1.721)$ & $<0.001$ & 0.003 & 0.621 & 0.506 \\
\hline & Caucasian & 1.770 & $(1.386-2.260)$ & $<0.001$ & $<0.001$ & 0.791 & 0.586 \\
\hline & Others & 1.487 & $(0.931-2.376)$ & 0.097 & 0.773 & 0.174 & 0.275 \\
\hline & Overall & 1.589 & $(1.396-1.808)$ & $<0.001$ & $<0.001$ & 0.978 & 0.965 \\
\hline \multirow{4}{*}{$\begin{array}{l}\text { Dominant } \\
\text { (G carriers vs. A/A) }\end{array}$} & Asian & 1.431 & $(1.227-1.670)$ & $<0.001$ & 0.349 & 0.187 & 0.196 \\
\hline & Caucasian & 1.727 & $(1.419-2.102)$ & $<0.001$ & $<0.001$ & 0.344 & 0.860 \\
\hline & Others & 1.739 & $(1.254-2.412)$ & 0.001 & 0.850 & 1.000 & 0.705 \\
\hline & Overall & 1.621 & $(1.430-1.837)$ & $<0.001$ & 0.001 & 0.113 & 0.166 \\
\hline
\end{tabular}

\begin{tabular}{|c|c|c|}
\hline $\begin{array}{l}\text { Study } \\
\text { ID }\end{array}$ & OR $(95 \% \mathrm{Cl})$ & $\stackrel{\%}{\text { Weight }}$ \\
\hline $\begin{array}{l}\text { Asian } \\
\text { Kimkong, l. (2011) } \\
\text { Zhao, S. X. (2010) } \\
\text { Kimura, H. (2009) } \\
\text { Wang, P. W. W.(2007) } \\
\text { Zhang, Q. (2006) } \\
\text { Han, S. Z. (2006) } \\
\text { Cho, H. J. (2006) } \\
\text { Weng, Y. C. (2005) } \\
\text { Iwama, S. (2005) } \\
\text { Wang,'P. W. (2004) } \\
\text { Mochizuki, M. (2003) } \\
\text { Bednarczuk, T.(2003) } \\
\text { Kinjo, Y. (2002) } \\
\text { Park, Y. J. (2000) } \\
\text { Awata, T. (1998) } \\
\text { Yanagawa. T. (1997) } \\
\text { Marron, M. P. (1997) } \\
\text { Subtotal (l-squared = 55.9\%, p = 0.003) }\end{array}$ & $\begin{array}{l}1.58(0.98,2.54) \\
1.28(1.13,1.45) \\
1.74(1.37,2.21) \\
1.45(0.97,2.15) \\
2.29(1.17,4.47) \\
1.70(1.17,2.48) \\
1.16(0.87,1.56) \\
1.97(1.10,3.51) \\
0.12(0.02,0.87) \\
0.83(0.40,0.98) \\
3.45(1.19,9.96) \\
2.06(1.30,3.26) \\
1.72(0.98,3.00) \\
1.47(0.90,2.40) \\
1.55(1.02,2.38) \\
1.83(1.08,2.49) \\
1.22(0.52,2.87) \\
1.48(1.27,1.72)\end{array}$ & $\begin{array}{l}3.22 \\
5.43 \\
4.79 \\
3.73 \\
2.25 \\
3.88 \\
4.42 \\
2.88 \\
0.38 \\
3.42 \\
1.18 \\
3.33 \\
2.77 \\
3.14 \\
3.58 \\
3.53 \\
1.64 \\
53.33\end{array}$ \\
\hline $\begin{array}{l}\text { Causasian } \\
\text { Khalilzadeh, O. (2009) } \\
\text { Esteghamati, A. (2009) } \\
\text { Tanrikulu, S. (2006) } \\
\text { Sahin, M. (2005) } \\
\text { Petrone, A. (2005) } \\
\text { Nakkash-Chmaisse, H. (2004) } \\
\text { Frydecka, I. (2004) } \\
\text { Vaidya, B. (2003) } \\
\text { Kalantari, T. (2003) } \\
\text { Bednarczuk, T. (2003) } \\
\text { Kouki, T. (2002) } \\
\text { Hadj Kacem, H. (2001) } \\
\text { Allahabadia, A. (2001) } \\
\text { Chistyakov,'D. A. (2000) } \\
\text { Heward, J.M. (1999) } \\
\text { Djlali-Saiah, l. (1998) } \\
\text { Braun, J.(1998) } \\
\text { Donner, H. (1997) } \\
\text { Subtotal (1-squared = 61.9\%, p=0.000) }\end{array}$ & $\begin{array}{l}5.13(1.43,18.42) \\
3.60(1.05,12.42) \\
0.69(0.30,1.62) \\
3.15(1.21,8.18) \\
2.09(1.14,3.84) \\
8.58(0.43,171.91) \\
1.39(0.89,2.80) \\
2.20(1.46,3.31) \\
0.79(0.41,1.51) \\
1.69(1.05,2.70) \\
1.84(0.81,3.33) \\
0.75(0.48,1.17) \\
2.48(1.03,3.78) \\
3.75(1.99,7.08) \\
2.48(1.55,3.98) \\
1.14(0.51,2.54) \\
1.53(0.80,2.93) \\
1.80(1.17,2.77) \\
1.77(1.39,2.28)\end{array}$ & $\begin{array}{l}0.87 \\
0.92 \\
1.65 \\
1.39 \\
2.52 \\
0.18 \\
2.13 \\
3.64 \\
2.34 \\
3.26 \\
2.11 \\
3.43 \\
3.56 \\
2.40 \\
3.27 \\
1.78 \\
2.33 \\
3.51 \\
41.30\end{array}$ \\
\hline $\begin{array}{l}\text { Others } \\
\text { Namo Cury, A. }(2008) \\
\text { Villanueva,'R. }(2000) \\
\text { Kouki, T. }(2000) \text {. } \\
\text { Chen,'Q. Y. }(2000) \\
\text { Subtotal }(1-\text { squared }=0.0 \%, p=0.773)\end{array}$ & $\begin{array}{l}1.51(0.58,3.88) \\
1.89(0.88,3.29) \\
1.64(0.49,5.49) \\
0.75(0.19,2.97) \\
1.49(0.93,2.38)\end{array}$ & $\begin{array}{l}1.40 \\
2.25 \\
0.96 \\
0.76 \\
5.37\end{array}$ \\
\hline Overall ( 1 -squared $=57.4 \%, p=0.000)$ & $1.59(1.40 .1 .81)$ & 100.00 \\
\hline NOTE: Weights are from random effects analysis & & \\
\hline
\end{tabular}

Figure 2. Forest plot of ORs of the G/G genotype when compared to the A allele carriers (G/A+A/A) (recessive model) in the Graves' patients. The squares and horizontal lines correspond to the study-specific OR and 95\% CI. The area of the squares reflects the study-specific weight. The diamond represents the pooled OR and $95 \%$ CI. OR, odds ratio; CI, confidence interval.

in subgroup analyses for ethnicity (Caucasians, Asians), the results were positive.
Publication bias. Funnel plot and Egger's test were performed to estimate the publication bias of studies. The results of Egger's 


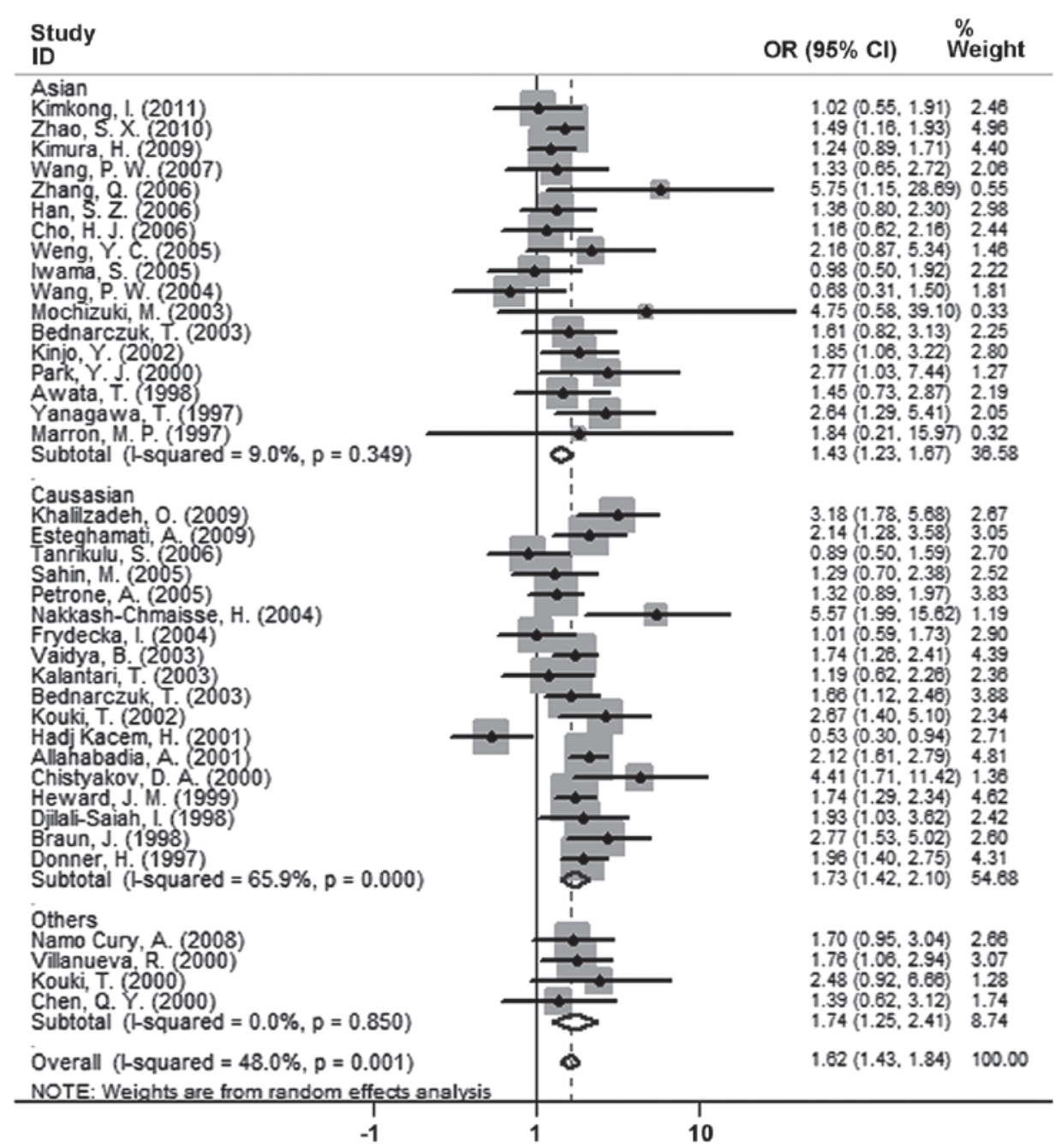

Figure 3. Forest plot of ORs of GD G allele carriers $(\mathrm{G} / \mathrm{G}+\mathrm{G} / \mathrm{A})$ when compared to the A/A genotype (dominant model) in the Graves' patients. The squares and horizontal lines correspond to the study-specific OR and 95\% CI. The area of the squares reflects the study-specific weight. The diamond represents the pooled OR and $95 \%$ CI. OR, odds ratio; CI, confidence interval.

test provided statistical evidence for funnel plot symmetry (for $\mathrm{G} / \mathrm{G}+\mathrm{G} / \mathrm{A}$ vs. A/A, p=0.166) (Table II).

\section{Discussion}

This meta-analysis examined the association of the CTLA-4 +49A/G polymorphism with GD and included 8,288 GD cases and 9,372 controls. Three studies were eliminated from the total 42 studies due to a p-value of $<0.05$ (p-value for Hardy-Weinberg equilibrium in control group) in these studies which induced significant publication bias. The results of Egger's test provided statistical evidence for funnel plot symmetry (for $\mathrm{G} / \mathrm{G}+\mathrm{G} / \mathrm{A}$ vs. $\mathrm{A} / \mathrm{A}, \mathrm{p}=0.166$ ). The overall results suggest that the variant genotypes were highly associated $(\mathrm{p}<0.01)$ with GD risk in all genetic models (additive model: OR, 1.443; 95\% CI, 1.319-1.578; $\mathrm{p}<0.001$; recessive model: OR, 1.589; 95\% CI, 1.396-1.808; $\mathrm{p}<0.001$; dominant model: OR, $1.621 ; 95 \%$ CI, 1.430-1.837; $\mathrm{p}<0.001)$. Similarly, in subgroup analyses for ethnicity (Caucasians, Asians), the results were positive.

GD is a disease with significant clinical consequences. The mechanism of GD is still relatively unknown. Although environmental factors, such as infection (4) and stress, are important in the process of Graves' disease in susceptible individuals, one study in twins suggests that $\sim 80 \%$ of the predisposition to GD is due to genetic factors (5). Single nucleotide polymorphisms (SNPs) can be used as a tool for investigating genetic variations and disease susceptibility. GD is an autoimmune antibody-mediated, thyroid-specific autoimmune disease. The CTLA-4 protein can transmit an inhibitory signal to T-cells and has a strong susceptibility in autoimmunity. CTLA-4 protein has recently been described as a gatekeeper of conjugation timing and reduced conjugation may protect against prolonged contact periods of cytotoxic $\mathrm{T}$ lymphocytes with autoantigen-defined targets (50). It has been in the centre of attention for its key role in autoimmunity. The $+49 \mathrm{~A} / \mathrm{G}$ polymorphism is one of the CTLA-4 three forms of polymorphisms. To date, a multitude of different studies were carried out concerning the association between the CTLA-4 +49A/G polymorphism and GD, but the results are inconsistent. In many studies (6-36) the results are positive, however in others (37-46) the results are negative.

This meta-analysis revealed a highly significant $(p<0.01)$ association between the CTLA- $4+49 \mathrm{~A} / \mathrm{G}$ polymorphism and 
GD risk, in both Asian and Caucasian subgroups. In conclusion, this meta-analysis suggests that the CTLA-4 +49A/G polymorphism is potentially associated with the risk of GD among Caucasians and Asians. Future, well-designed, large scale studies are necessary to validate this association in different populations.

\section{Acknowledgements}

This work was financially supported by the National Science Foundation of China (nos. 30960152, 30871232, 31170735), the Nature Science Foundation of Yunnan Province (no. 2008C043M) and the Fund of State Key Laboratory of Genetics Resources and Evolution (no. GREKF10-07).

\section{References}

1. Wang $\mathrm{C}$ and Crapo LM: The epidemiology of thyroid disease and implications for screening. Endocrinol Metab Clin North Am 26: 189-218, 1997.

2. Hollowell JG, Staehling NW, Flanders WD, Hannon WH, Gunter EW, Spencer CA and Braverman LE: Serum TSH, T(4), and thyroid antibodies in the United States population (1988 to 1994): National Health and Nutrition Examination Survey (NHANES III). J Clin Endocrinol Metab 87: 489-499, 2002.

3. Chen XWW, Chen GL, Zhang KZ, Zhang FL, et al: The effect of salt iodization for 10 years on the prevalences of endemic goiter and hyperthyroidism. Chin J Endocrinol Metab 18: 342-344, 2000.

4. Onodera $\mathrm{T}$ and Awaya A: Anti-thyroglobulin antibodies induced with recombinant reovirus infection in $\mathrm{BALB} / \mathrm{c}$ mice. Immunology 71: 581-585, 1990.

5. Brix TH, Kyvik KO, Christensen K and Hegedus L: Evidence for a major role of heredity in Graves' disease: a population-based study of two Danish twin cohorts. J Clin Endocrinol Metab 86: 930-934, 2001.

6. Yanagawa T, Taniyama M, Enomoto S, Gomi K, Maruyama H, Ban Y and Saruta T: CTLA4 gene polymorphism confers susceptibility to Graves' disease in Japanese. Thyroid 7: 843-846, 1997.

7. Marron MP, Raffel LJ, Garchon HJ, et al: Insulin-dependent diabetes mellitus (IDDM) is associated with CTLA4 polymorphisms in multiple ethnic groups. Hum Mol Genet 6: 1275-1282, 1997.

8. Donner H, Rau H, Walfish PG, et al: CTLA4 alanine-17 confers genetic susceptibility to Graves' disease and to type 1 diabetes mellitus. J Clin Endocrinol Metab 82: 143-146, 1997.

9. Veeramuthumari P, Isabel W and Kannan K: A Study on the level of T(3), T(4), TSH and the association of A/G polymorphism with CTLA-4 gene in Graves' hyperthyroidism among South Indian population. Ind J Clin Biochem 26: 66-69, 2011.

10. Zhao SX, Pan CM, Cao HM, et al: Association of the CTLA4 gene with Graves' disease in the Chinese Han population. PloS One 5: e9821, 2010.

11. Kimura H, Kato Y, Shimizu S, Takano K and Sato K: Association of polymorphism at position 49 in exon 1 of the cytotoxic T-lymphocyte-associated factor 4 gene with Graves' disease refractory to medical treatment, but not with amiodaroneassociated thyroid dysfunction. Thyroid 19: 975-981, 2009.

12. Khalilzadeh O, Mojazi Amiri H, Tahvildari M, et al: Pretibial myxedema is associated with polymorphism in exon 1 of CTLA-4 gene in patients with Graves' ophthalmopathy. Arch Dermatol Res 301: 719-723, 2009.

13. Esteghamati A, Khalilzadeh O, Mobarra Z, et al: Association of CTLA-4 gene polymorphism with Graves' disease and ophthalmopathy in Iranian patients. Eur J Intern Med 20: 424-428, 2009.

14. Chong KK, Chiang SW, Wong GW, et al: Association of CTLA-4 and IL-13 gene polymorphisms with Graves' disease and ophthalmopathy in Chinese children. Invest Ophthalmol Vis Sci 49: 2409-2415, 2008.

15. Wang PW, Chen IY, Liu RT, Hsieh CJ, Hsi E and Juo SH: Cytotoxic T lymphocyte-associated molecule-4 gene polymorphism and hyperthyroid Graves' disease relapse after antithyroid drug withdrawal: a follow-up study. J Clin Endocrinol Metab 92: 2513-2518, 2007.
16. Zhang Q, Yang YM and Lv XY: Association of Graves' disease and Graves' ophthalmopathy with the polymorphisms in promoter and exon 1 of cytotoxic T lymphocyte associated antigen-4 gene. J Zhejiang Univ Sci B 7: 887-891, 2006.

17. Tanrikulu S, Erbil Y, Ademoglu E, et al: The predictive value of CTLA-4 and Tg polymorphisms in the recurrence of Graves disease after antithyroid withdrawal. Endocrine 30: 377-381, 2006.

18. Han SZ, Zhang SH, Li R, Zhang WY and Li Y: The common $-318 \mathrm{C} / \mathrm{T}$ polymorphism in the promoter region of CTLA4 gene is associated with reduced risk of ophthalmopathy in Chinese Graves' patients. Int J Immunogenet 33: 281-287, 2006.

19. Sahin M, Erdogan MF and Erdogan G: Cytotoxic T lymphocyteassociated molecule-4 polymorphisms in Turkish Graves' disease patients and association with probability of remission after antithyroid therapy. Eur J Intern Med 16: 352-355, 2005.

20. Petrone A, Giorgi G, Galgani A, et al: CT60 single nucleotide polymorphisms of the cytotoxic T-lymphocyte-associated antigen-4 gene region is associated with Graves' disease in an Italian population. Thyroid 15: 232-238, 2005.

21. Wang PW, Liu RT, Juo SH, et al: Cytotoxic T lymphocyteassociated molecule- 4 polymorphism and relapse of Graves hyperthyroidism after antithyroid withdrawal. J Clin Endocrinol Metab 89: 169-173, 2004.

22. Nakkash-Chmaisse H, Makki RF, Abdelhamid E, Fakhoury H, Salti NN and Salti I: CTLA-4 gene polymorphism and its association with Graves' disease in the Lebanese population. Eur J Immunogenet 31: 141-143, 2004.

23. Vaidya B, Oakes EJ, Imrie H, Dickinson AJ, Perros P, KendallTaylor P and Pearce SH: CTLA4 gene and Graves' disease: association of Graves' disease with the CTLA4 exon 1 and intron 1 polymorphisms, but not with the promoter polymorphism. Clin Endocrinol 58: 732-735, 2003.

24. Mochizuki M, Amemiya S, Kobayashi K, et al: Association of the CTLA-4 gene 49A/G polymorphism with type 1 diabetes and autoimmune thyroid disease in Japanese children. Diabetes Care 26: 843-847, 2003

25. Kalantari T, Mostafavi H, Pezeshki AM, Farjadian S, Doroudchi M, Yeganeh F and Ghaderi A: Exon-1 polymorphism of ctla-4 gene in Iranian patients with Graves' disease. Autoimmunity 36: 313-316, 2003.

26. Bednarczuk T, Hiromatsu Y, Fukutani T, Jazdzewski K, Miskiewicz P, Osikowska $\mathrm{M}$ and Nauman J: Association of cytotoxic T-lymphocyte-associated antigen-4 (CTLA-4) gene polymorphism and non-genetic factors with Graves' ophthalmopathy in European and Japanese populations. European J Endocrinol 148: 13-18, 2003.

27. Yung E, Cheng PS, Fok TF and Wong GW: CTLA-4 gene A-G polymorphism and childhood Graves' disease. Clin Endocrinol 56: 649-653, 2002

28. Kouki T, Gardine CA, Yanagawa T and Degroot LJ: Relation of three polymorphisms of the CTLA-4 gene in patients with Graves' disease. J Endocrinol Invest 25: 208-213, 2002.

29. Kinjo Y, Takasu N, Komiya I, et al: Remission of Graves' hyperthyroidism and $\mathrm{A} / \mathrm{G}$ polymorphism at position 49 in exon 1 of cytotoxic T lymphocyte-associated molecule- 4 gene. J Clin Endocrinol Metab 87: 2593-2596, 2002.

30. Hadj Kacem H, Bellassoued M, Bougacha-Elleuch N, Abid M and Ayadi H: CTLA-4 gene polymorphisms in Tunisian patients with Graves' disease. Clin Immunol 101: 361-365, 2001.

31. Park YJ, Chung HK, Park DJ, Kim WB, Kim SW, Koh JJ and Cho BY: Polymorphism in the promoter and exon 1 of the cytotoxic T lymphocyte antigen-4 gene associated with autoimmune thyroid disease in Koreans. Thyroid 10: 453-459, 2000.

32. Kouki T, Sawai Y, Gardine CA, Fisfalen ME, Alegre ML and DeGroot LJ: CTLA-4 gene polymorphism at position 49 in exon 1 reduces the inhibitory function of CTLA- 4 and contributes to the pathogenesis of Graves' disease. J Immunol 165: 6606-6611, 2000.

33. Chistyakov DA, Savost'anov KV, Turakulov RI, et al: Complex association analysis of Graves disease using a set of polymorphic markers. Mol Genet Metab 70: 214-218, 2000.

34. Heward JM, Allahabadia A, Armitage M, et al: The development of Graves' disease and the CTLA-4 gene on chromosome 2q33. J Clin Endocrinol Metab 84: 2398-2401, 1999.

35. Braun J, Donner H, Siegmund T, Walfish PG, Usadel KH and Badenhoop K: CTLA-4 promoter variants in patients with Graves' disease and Hashimoto's thyroiditis. Tissue Antigens 51: $563-566,1998$. 
36. Awata T, Kurihara S, Iitaka M, et al: Association of CTLA-4 gene A-G polymorphism (IDDM12 locus) with acute-onset and insulin-depleted IDDM as well as autoimmune thyroid disease (Graves' disease and Hashimoto's thyroiditis) in the Japanese population. Diabetes 47: 128-129, 1998 .

37. Kimkong I, Nakkuntod J, Sae-Ngow S, Snabboon T, Avihingsanon $\mathrm{Y}$ and Hirankarn N: Association between CTLA-4 polymorphisms and the susceptibility to systemic lupus erythematosus and Graves' disease in Thai population. Asian Pac J Allergy Immunol 29: 229-235, 2011.

38. Namo Cury A, Longui CA, Kochi C, et al: Graves' disease in Brazilian children and adults: lack of genetic association with CTLA-4 +49A > G polymorphism. Horm Res 70: 36-41, 2008.

39. Cho HJ, Chung JH, Kim IS, Kim HJ, Cho SH, Ki CS and Kim JW: Lack of a genetic association between the CTLA-4 gene and Graves' disease in Koreans. Thyroid 16: 237-241, 2006.

40. Weng YC, Wu MJ and Lin WS: CT60 single nucleotide polymorphism of the CTLA-4 gene is associated with susceptibility to Graves' disease in the Taiwanese population. Ann Clin Lab Sci 35: 259-264, 2005

41. Iwama S, Ikezaki A, Kikuoka N, et al: Association of HLA-DR, -DQ genotype and CTLA-4 gene polymorphism with Graves' disease in Japanese children. Horm Res 63: 55-60, 2005.

42. Frydecka I, Daroszewski J, Suwalska K, et al: CTLA-4 (CD152) gene polymorphism at position 49 in exon 1 in Graves' disease in a Polish population of the Lower Silesian region. Arch Immunol Ther Exp (Warsz) 52: 369-374, 2004.
43. Allahabadia A, Heward JM, Nithiyananthan R, et al: MHC class II region, CTLA4 gene, and ophthalmopathy in patients with Graves' disease. Lancet 358: 984-985, 2001.

44. Villanueva R, Inzerillo AM, Tomer Y, et al: Limited genetic susceptibility to severe Graves' ophthalmopathy: no role for CTLA-4 but evidence for an environmental etiology. Thyroid 10: 791-798, 2000.

45. Chen QY, Nadell D, Zhang XY, et al: The human leukocyte antigen HLA DRB3*020/DQA1*0501 haplotype is associated with Graves' disease in African Americans. J Clin Endocrinol Metab 85: 1545-1549, 2000.

46. Djilali-Saiah I, Larger E, Harfouch-Hammoud E, et al: No major role for the CTLA-4 gene in the association of autoimmune thyroid disease with IDDM. Diabetes 47: 125-127, 1998.

47. DerSimonian R and Laird N: Meta-analysis in clinical trials Control Clin Trials 7: 177-188, 1986.

48. Mantel N and Haenszel W: Statistical aspects of the analysis of data from retrospective studies of disease. J Natl Cancer Inst 22: 719-748, 1959.

49. Egger M, Davey Smith G, Schneider M and Minder C: Bias in meta-analysis detected by a simple, graphical test. BMJ 315: 629-634, 1997.

50. Schneider H, Downey J, Smith A, et al: Reversal of the TCR stop signal by CTLA-4. Science 313: 1972-1975, 2006. 